\title{
A textura polifônica de grupos teatrais contemporâneos
}

\section{0 fio}

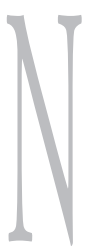

os últimos anos, temos investigado alguns aspectos da cena teatral contemporânea, tanto no âmbito artístico quanto no acadêmico, que implicam no redimensionamento das noçôes de texto dramático e dramaturgia, como pensadas tanto na formação do artista como na criação cênica mineira contemporânea. ${ }^{1}$ Já na dissertação de mestrado $O s$ processos enunciativos do discurso cênico: o Método Grotowski sob a perspectiva da Teoria dos Atos de Fala e da Teoria Semiolingüistica (2000), buscamos ampliar o alcance dos estudos da Análise do Discurso, propondo, no interior da Teoria dos Atos de Fala - a qual trabalha com o discurso "sério", não ficcional - a análise do discur-

\section{Nina Caetano}

so produzido na cena e pela cena: a partir do postulado de $\mathrm{Barba}^{2}$ e da definição de acontecimento teatral proposta por Grotovski (1992) como a relação existente entre o ator e o espectador, buscava-se analisar o texto como o discurso produzido em cena e na relação/diálogo com o espectador. A análise empreendida buscava aproximar os processos enunciativos do discurso cênico da noção de engajamento atoral e do ato performático.

No âmbito artístico, optamos por verticalizar a pesquisa no campo da dramaturgia a partir de dois vetores: a construção processual e a linguagem épico-dramática. Em 2001, junto à Maldita, companhia de investigação teatral de que fazemos parte, ${ }^{3}$ começamos uma pesquisa prática dos mecanismos épico-dramáticos, in-

Nina Caetano é dramaturga e professora do Departamento de Artes da Universidade Federal de Ouro Preto (UFOP).

1 Basta analisar os currículos dos cursos de graduação em Teatro do Brasil, mais especificamente das universidades federais mineiras, os quais concentram os estudos da dramaturgia na análise de obras literárias.

2 Barba (1995, p. 69) vê a dramaturgia como uma tessitura de açôes, considerando "tudo o que trabalha diretamente com a atenção do espectador em sua compreensão, suas emoções, sua cinestesia" como uma ação.

3 A companhia Maldita é composta pela dramaturga Nina Caetano - autora do presente artigo - pela atriz Lissandra Guimarães, pela atriz e dramaturga Letícia Andrade, pelos diretores e atores Amaury Borges e Lenine Martins e pela cenógrafa Ines Linke, além da produtora e atriz Joyce Malta. 
vestigação desenvolvida em todos os níveis da encenação. $\mathrm{O}$ espetáculo Casa das Misericórdias, fruto do Projeto Cena $3 \times 4,{ }^{4}$ - concebido pelo grupo e realizado em parceria com o Galpão Cine Horto - foi o primeiro resultado dessa pesquisa. Produzida como work in process, a Casa era encenada, inicialmente, em uma casa-bar de Belo Horizonte.

No âmbito acadêmico, a partir de questôes desencadeadas pelos processos de criação dos quais participamos - bem como por aqueles com os quais tivemos contato na coordenação do $3 x 4$ - propusemos a criação de uma linha de pesquisa no Departamento de Artes da UFOP $^{5}$ - Poéticas e Processos de Criação do Texto $e$ da Cena - na qual buscamos desenvolver pesquisas de caráter teórico-prático sobre questóes relativas à dramaturgia da cena. ${ }^{6}$

$\mathrm{O}$ presente artigo nasce, justamente, da convergência dessas questôes e pretende investigar de que modo os processos de criação balizados em relaçóes colaborativas entre os criadores da cena teatral implicam no desenvolvimento de uma dramaturgia polifônica. Buscamos perceber como tais relações podem ser vistas não só como produtoras de um discurso polifônico, mas como este se manifesta, claramente, em termos não só de uma configuração dramatúrgica, ou seja, de uma linguagem estético-ideológica, mas também de uma nova pedagogia teatral, não mais centrada na figura do encenador.

Buscando a investigação da autoria coletiva, consideraremos a seguinte questão: quais as características de um texto-espetáculo produzido em processo? Evidentemente, a pergunta envolve questóes de naturezas diversas, embora interdependentes. Em primeiro lugar, os aspectos discursivos. Segundo Pavis (1999, p. 80), no trabalho coletivo ocorre o que Brecht denomina "socialização do saber", ou seja, "a encenação não representa mais a palavra de um autor (seja este autor dramático, encenador ou ator), porém a marca mais ou menos visível e assumida da palavra coletiva”. Nesse sentido, a questão que se coloca refere-se aos rastros que os sujeitos do discurso deixam no enunciado cênico, à "colocação em discursos de sistemas significantes na enunciação cênica” (Pavis, 1999, p. 80), possibilitando a apreensão de seus mecanismos - e estratégias - discursivos através das marcas da enunciação teatral.

Em segundo lugar, temos questóes de natureza estética. A apreensão das marcas discursivas e de múltipla autoria só é possível através de uma sistematização do processo criativo em si, buscando perceber, inclusive, as soluções formais que tal processo imprime à obra. A questão que propomos se articula, então, em outro

4 O projeto, que já contou com orientação de Antônio Araújo (Teatro da Vertigem), Luis Alberto de Abreu (O Livro de Jó) e Tiche Viana (Barracão Teatro), além do diretor Francisco Medeiros, propõe a investigação dos processos colaborativos, no diálogo entre as criaçōes de quatro grupos teatrais compostos por atores, diretores e dramaturgos.

5 O DEART comporta, hoje, um Curso de Graduação em Artes Cênicas com duas modalidades: Licenciatura e Bacharelado, que abarcam as disciplinas de Dramaturgia que ministramos.

6 Em 2003/2004, desenvolvemos os projetos Dramaturgia em processo e a escrita da cena: as marcas da polifonia no texto contemporâneo (PIP/UFOP) e Histórias no crepuisculo da memória: "texturas" teatrais de causos e lembranças de velhos (PIVIC/UFOP). Em 2005/2006, o projeto do PIP/UFOP, Processos de Criação de uma Dramaturgia Contemporânea, bem como aquele desenvolvido no âmbito do PIVIC/ UFOP, Dramaturgia da cena: a escrita no corpo do ator, investigavam o conceito de dramaturgia da cena a partir de procedimentos colaborativos. Em agosto do presente ano, demos início à investigação de mecanismos de transcriação da obra literária de Jean Genet a partir da aproximação com material documental sobre os presídios brasileiros no projeto Notícia de jornal, imagem e transcriação teatral da obra literária de Jean Genet (PIP/UFOP). 
patamar: como se organiza a linguagem artística quando fruto de um pensamento coletivo, de uma visão artística compartilhada?

Ou seja, a dramaturgia polifônica, produzida no interior dos grupos teatrais contemporâneos, se configura como um modelo estéticoideológico? Tal modelo pode ser pensado em termos de procedimentos e de um modus operandi comum? Esse modus operandi implica no desenvolvimento de procedimentos estéticos e na construção de uma linguagem também "comum", perceptível no material dramatúrgico produzido por esses coletivos teatrais?

\section{Tear}

Dentro da maior parte das teorias dos grandes teatrólogos do século XX, a idéia de uma mente única, origem da criação, é recorrente. Tradicionalmente, esse lugar era ocupado pelo dramaturgo. Porém, com o advento do "encenador" (cf. Roubine, 1998), esse se tornou o grande eixo e "autor" da cena. Os estudos sobre as experiências contemporâneas demonstram isso:

Ao encenador-orquestrador da polifonia cênica, na operação dos fluxos intersemióticos, de partituras de textos, imagem, corporeidades e suportes - e não ao dramaturgo - cabe a guia da cena contemporânea. Encarna, nesse sentido, a função de "homem total do teatro" preconizada pelo teatralista Edward Gordon Craig (Cohen, 2004, p. xxviii).

De todos os teóricos da cena (de Craig a Artaud e, até mesmo, Grotowski), parece que apenas Brecht - referência da maior parte dos grupos teatrais que, a partir da década de 60 , começam a pensar a criação de maneira compartilhada - aponta para uma relação coletivizada. Mas, mesmo a criação coletiva, se não pensava em uma mente única, centrava em uma determinada função o papel sagrado do demiurgo da cena: o ator. Com a proliferação de espetáculos construídos em um sistema de criação coletiva, principalmente nas décadas de 60 e 70 , é que vemos abrir-se um campo fértil para a investigação de uma dramaturgia do ator:

"es necesario pasar de la condición de histrión a la condición de actor, de la condición de intérprete a la de creador que tiene el derecho y el deber de intervenir (metodológicamente) en todos los niveles y aspectos del proceso de producción del discurso del espectáculo y en las relaciones de éste con el público"?

No começo dos anos 90, no Brasil - mais especificamente em São Paulo - começa a se aprofundar a pesquisa em torno da criação de uma obra teatral por meio do processo colaborativo. O Teatro da Vertigem - Trilogia Bíblica - e a Escola Livre de Santo André são referências importantes deste processo. Os estudos sobre o tema têm sofrido um crescente aumento, principalmente no que concerne ao campo específico da encenação teatral e às questôes relativas aos processos coletivos de criação cênica ${ }^{8}$, o que ratifica sua importância na contemporaneidade.

Dentro dos estudos da linguagem ${ }^{9}$, a função autor já vem sendo discutida, desde a década de 60, como uma função em crise. Entre os diversos estudos relacionados ${ }^{10}$, podemos citar

7 Buenaventura, E. La dramacturgia del actor. Disponível em: <www.teatrodelpueblo.org.ar>. Acessado em: 20/03/2006.

8 Destacam-se os estudos realizados na USP: Renato Cohen, Sílvia Fernandes, Antônio Araújo, Rubens Rewald e outros.

9 Teoria da Literatura, Semiologia, Análise do Discurso.

10 O conceito de genotexto e intertextualidade (Kristeva), o estatuto e "a morte do autor" (Barthes). 
aquele desenvolvido por Bakhtin (já na década de 30) acerca da obra de Dostoiévski, e o conseqüente desenvolvimento do conceito de polifonia (Bakhtin, 1987), o qual pressupõe que, no interior da obra, do texto, ressoem vozes equipolentes que - não sujeitas a nenhuma espécie de hierarquização, seja em relação a um organizador externo ou a uma outra voz - relacionamse em pé de igualdade. $\mathrm{O}$ conceito abarca, ain$\mathrm{da}$, dois aspectos fundamentais e que apontam, no nosso entender, para sua aplicação teatral a partir de uma perspectiva estético-ideológica.

Se, em termos de romance, o que prevalece é o tipo monológico (o qual pressupõe um herói definido, "acabado"), no teatro a tradição brechtiana inaugura, em termos do discurso épico, o "homem em processo", absolutamente definido na originalidade de Dostoiévski: construído no contato com o outro (essa é a segunda característica), sua consciência é inacabada. Isso implica que também o discurso esteja em processo. $\mathrm{Na}$ obra polifônica, o diálogo - e o confronto - é característica inerente da relação entre as vozes, sendo constitutivo e matéria formal11. Evidentemente, não estamos nos referindo aqui ao diálogo dramático, mas ao diálogo entre as diversas matérias significantes do "discurso" cênico, entendido como a materialidade proposta por Artaud: a "linguagem do palco".

Se nos estudos da linguagem a discussão parece já bastante avançada, no teatro a crise parece ser bem mais recente e relacionada aos paradigmas da contemporaneidade. ${ }^{12}$ Nesse sentido, o estudo de Foucault mantém sua atualidade. De todas as questôes por ele colocadas, a que queríamos pontuar diz respeito à questão da autoria como ato transgressor e, no reverso, como ato conservador.

Os textos, os livros, os discursos começaram a ter realmente autores (...) na medida em que o autor podia ser punido, ou seja, na medida em que os discursos podiam ser transgressores. (...) $\mathrm{O}$ discurso (...) não era originalmente um produto, uma coisa, um bem: era essencialmente um ato. (...) Ele foi historicamente um gesto carregado de riscos antes de ser um bem extraído de um circuito de propriedades (Foucault, 2006, p. 275).

Nesse sentido, deslocar o conceito de autoria do sentido de propriedade, pensando a criação como um lugar de saberes socializados, aponta para a criação como ato político.

O novo paradigma estético tem implicaçōes ético-políticas porque quem fala em criação, fala em responsabilidade da instância criadora em relação à coisa criada (...). Mas essa escolha ética não mais emana de uma enunciação transcendente, de um código de lei ou de um deus único e todo-poderoso. A própria gênese da enunciação encontra-se tomada pelo movimento de criação processual (Guattari, 1992, p. 137).

Pensar a dramaturgia contemporânea é pensá-la, então, não como enunciado, mas como enunciação. E enunciação coletiva e polissêmica. Partindo do pensamento teatral de Artaud e tendo como balizas teóricas não só o conceito de polifonia, mas também o aparato

11 "Dostoievski procura captar as etapas propriamente ditas em sua simultaneidade, confrontá-las e contrapôlas dramaticamente e não estendê-las numa série em formação. (...) Essa tendência (...) a ver tudo como coexistente, perceber e mostrar tudo em contigüidade e simultaneidade, como que situado no espaço e não no tempo, leva Dostoiévski a dramatizar no espaço até as contradiçōes e etapas interiores do desenvolvimento de um indivíduo" (Bakhtin, 1987, p. 22).

12 Espetacularização. Real/virtual. A internet, a pirataria cibernética. Teoria do Caos, relativismo, pensamento "em rede", rizomas, territórios etc. 
conceitual de Deleuze e Guattari, ${ }^{13}$ deve-se interrogar a dramaturgia da cena não só por intermédio da análise do processo criativo, mas também do texto resultante.

Mais especificamente, no âmbito dessa interrogação, deve-se buscar a fusão entre a pesquisa poética da cena e a análise discursiva. Deste modo, o foco de análise desloca-se da prática coletiva de encenação para a própria linguagem artística no seu modo de articulação discursiva ou, mais precisamente, no modo como as instâncias enunciativas produzem o texto-espetáculo. Assim, a abordagem do fenômeno teatral acontece em sua totalidade e, além disso, requer o desenvolvimento de novas metodologias ou abordagens, que tenham em vista o aspecto discursivo do texto-espetáculo.

\section{Emaranhados do objeto}

Buscando entender a dramaturgia como criação produzida na e pela cena, chegamos a algumas premissas teóricas. Em primeiro lugar, temos como pressuposto o entendimento do texto teatral não como "literatura dramática", mas como um discurso engendrado em um processo enunciativo específico, que imprime marcas ao "texto" resultante. A essa escrita cênica - trabalho de tessitura de açôes, uma vez que, como salienta Barba (1995, p. 69), "as ações só são operantes quando estão entrelaçadas, quando se tornam textura" - nomearemos dramaturgia da cena, porque "a palavra 'texto', antes de se referir a um texto escrito ou falado, impresso ou manuscrito, significa 'tecendo junto'...” (Barba, 1995, p. 69).

Outro aspecto da questão, profundamente ligado a esse, diz respeito à ação dramática.
Deslocando o conceito de texto para a cena, deslocamos também a ação para o plano concreto. Desse modo, dilatamos o conceito de ação, vigente desde Aristóteles, que passa a ter sua relação ampliada para além do nível dramático, englobando os diversos níveis da encenação: "todas as relaçôes, todas as interaçōes entre as personagens ou entre as personagens e as luzes, os sons e os espaços, são ações" (Barba, 1995, p. 69). Tal deslocamento do sentido de ação contribui para a investigação do conceito de dramaturgia da cena, cuja origem e fim se localizam na idéia de evento teatral, no encontro entre espectador e ator. Ou seja, passamos a pensar dramaturgia não mais como "imitação de ações", mas como composição das ações no espaço e tempo da cena:

Essa linguagem... tira sua eficácia de sua criação espontânea em cena [...] Os espetáculos serão feitos diretamente no palco... o que não quer dizer que esses espetáculos não serão rigorosamente compostos e estabelecidos de forma definitiva antes de serem encenados (Artaud apud Todorov, 2003, p. 282-3).

E, finalmente, a última premissa norteadora deste texto diz respeito a um determinado modo de articulação coletiva dos elementos cênicos, que pressupõe um "pensar o fazer" absolutamente socializado, uma produção de sentido compartilhada por todos os criadores. Tal modo de articulação é o processo de criação colaborativa, "metodologia de criação em que todos os integrantes, a partir de suas funções artísticas específicas, têm igual espaço propositivo, sem qualquer espécie de hierarquias, produzindo uma obra cuja autoria é compartilhada por todos" (Araújo, 2002, p. 87).

13 Absolutamente relacionado à questão da polifonia, principalmente a noção de "construção rizomática". 


\section{0 tecido de vozes}

Tendo como pontos de investigação tanto a exploração cênica (não convencional) de espaços da memória coletiva como a construção de uma obra em processo, que busca a horizontalidade nas relações criativas, a experiência do Teatro da Vertigem é, para nós, paradigmática em função de alguns aspectos que gostaríamos de abordar.

Tendo como eixo teórico as práticas colaborativas do Teatro da Vertigem, ${ }^{14}$ em 2003, em Belo Horizonte, foi proposta pela Maldita uma experiência na qual dialogaríamos nosso processo de criação com os processos de outros coletivos teatrais: o Projeto Cena $3 \times 4$. A pesquisa, coincidentemente, acabou sendo também uma experiência de ocupação de espaços não convencionais - a não ocupação do edifício-teatro ou de espaços convencionalmente destinados à atividade teatral - na qual buscamos perceber em que medida a dramaturgia de grupo se configura como linguagem estético-ideológica ${ }^{15}$ ou como "poesia do espaço", dramaturgia da cena.

Uma vez que, no processo colaborativo, o texto não representa mais a voz de um autor, mas é engendrado no embate das diversas vozes envolvidas na criação, podemos, para usar o conceito caro a Bakhtin, pensá-lo como um sistema polifônico. ${ }^{16} \mathrm{E}$ tal sistema, tal embate no "corpo-a-corpo da sala de ensaio" (Araújo, 2002, p. 157), imprime determinadas soluções formais ao texto resultante. E mais: a impressão, em nível ficcional, das marcas desse acordo precário, tenso, entre as vozes, no texto produ- zido nessa relação, é um modo de articular as diversas dramaturgias da cena: a dramaturgia do espaço, da luz, dos corpos, na escritura.

Nesse texto, pensamos as questóes colocadas não da maneira como usualmente são abordadas, como práticas de encenação ou de interpretação, mas, de modo mais amplo, como práticas de criação cênica, ou seja, incluindo as práticas do dramaturgo e dos outros criadores da cena. Especificamente em relação à dramaturgia, ou ao objeto que denominamos texto, preferimos deslocar a discussão do trabalho específico do dramaturgo para o sentido da cena. Como Roubine (1998, p. 77) salienta, "estamos aqui diante de uma nova concepção de texto dramático. Não mais uma 'obra', mas aquilo que os anglo-saxões chamam de work in progress, um material aberto e transformável”.

Essa nova concepção de texto dramático, inserido no bojo de uma prática coletiva de criação, implica na discussão de um "cacife ideológico" ainda imperante na criação cênica: o status do criador, ou seja, da autoria: "trata-se de saber em que mãos cairá o poder artístico, (...) a quem caberá tomar as opções fundamentais, e quem levará aquilo que antigamente se chamava glória” (Roubine, 1998, p. 45).

Pensar na prática coletiva de criação cênica coloca em questão não somente os aspectos propriamente estéticos da cena, mas também um posicionamento ideológico. Tal posicionamento implicaria em soluções estéticas? Pensar a escrita da cena como um cruzamento de vozes eqüipolentes implica no redimensionamento da linguagem da cena?

14 Oficina de Processo Colaborativo ministrada por Antônio Araújo e Luís Alberto de Abreu, em 2001, no Galpão Cine Horto.

15 Segundo se faz notar por uma grande parte dos estudos voltados à questão da narrativa (Szondi, Pavis, Sílvia Fernandes, entre outros), a presença do elemento narrativo como desarticulador do cânone tradicional do texto teatral (de base dialético-dialógica) tem encontrado expressão tanto nas encenações como nos textos teatrais contemporâneos.

16 "A multiplicidade de vozes e consciências independentes e imiscíveis e a autêntica polifonia de vozes plenivalentes...” (Bakhtin, 1987, p. 2). 
Levantadas essas questôes, a Maldita buscou investigar, dentro do Cena $3 \times 4$, os processos de criação colaborativa, principalmente no que concerne à especificidade de cada função artística, aos mecanismos de horizontalização da criação, além dos aspectos formais que tal contrato impõe ao texto-espetáculo resultante.

Mas, para além das questóes estéticas, o processo específico da Maldita - que culminou no espetáculo Casa das Misericórdias - propôs também a discussão das estruturas do poder. Como, para nós, havia a confluência entre aspectos estéticos e ideológicos, buscamos, a partir da investigação de mecanismos épico-dramáticos em todos os níveis da encenação, discutir, balizados nos pressupostos teóricos de Foucault e centrados na questão da loucura, a relação entre indivíduo e sociedade.

Além de Foucault, foram bases do trabalho a teoria brechtiana, mas também a obra e a vida de Lautréamont, Artur Bispo do Rosário, Maura Lopes Cançado e, principalmente, Antonin Artaud. Nossa investigação nos levou ao conceito de arquitetura do abandono e à exploração de espaços esquecidos pela coletividade, abandonados como as personas que transitavam em cena: Laurinda, a única interna do manicômio judiciário feminino e o guarda que quer trazê-la para Deus.

$\mathrm{Na}$ função de dramaturga ainda foi investigada a questão que chamaremos de notação: como a dramaturgia pode concretizar, em termos escritos, toda a composição que existe entre o gesto e a palavra, o corpo e o espaço? Como registrar a simultaneidade de ações ou o tapete sonoro que emprestam sentido à cena?

Guarda - O Guarda bem sabe que Laurinda o provoca! É o seu exercício diário. Todos os dias, o Guarda faz um esforço sobre humano para não invadir a cela daquela puta, louca, piranha.

Laurinda - Laurinda não se continha, não tinha limite: ela era doida, não era? Se isso dava ao guarda direito de fazer o que quisesse, por que não daria a ela?

Guarda - O Guarda respira fundo e continua: Então ele os ensinou, dizendo: Pai Nosso que estais no céu, santificado seja o vosso nome; venha a nós o vosso reino, seja feita a vossa vontade assim na terra como no céu. O pão nosso de cada dia nos dai hoje. Perdoai as nossas ofensas, assim como nós perdoamos a quem nos tem ofendido... Vê? Laurinda continuava pelada... Apesar das roupas que ele trazia pra ela, ela ficava pelada, me tentando, meu Pai... (pausa. Ele continua mais baixo) $\mathrm{E}$ não nos deixeis cair em tentação... mas livrai-nos do mal. Amém.

Laurinda - Ai, meus anjos caralhudos, os anjos são sete, são grandes, de espadas flamejantes rasgando a Bendita Buceta de Laurinda... A tentação de Laurinda era a fé do Guarda. E ela provocava: Ave, Laurinda. Cheia de racha. Bendita sois vós entre as mulheres: peitudas, bundudas, bucetudas!

Guarda - Ah, Laurinda... não blasfema!

Laurinda - Laurinda acaricia a Bendita...

"O meu pão de cada dia, me dá hoje...

Guarda - Nem só de pão vive o homem, mas de toda palavra que sai da boca de Deus!

Laurinda - O senhor é Deus? ${ }^{17}$

A articulação polifônica na trama dramatúrgica acontece na superfície do texto, quando este deixa de ser fiado na construção das personagens e passa a ser "tramado" por personas enunciadoras do discurso, ou seja, por sujeitos representativos do corpo social. Esse traço aproxima a experiência dos criadores da matéria cria-

17 Trecho do espetáculo Casa das Misericórdias, em que as falas são, muitas vezes, simultâneas: por exemplo, a reza pornográfica de Laurinda atravessa a reza do Guarda. 
da, e talvez por isso seja mesmo uma marca da dramaturgia contemporânea: o engajamento do sujeito criador (Ryngaert, 1997). Um engajamento que, sem dúvida, é uma proposta política.

Em relação à questão política da cena contemporânea, Lehmann (2002, p. 292) aponta para um aspecto interessante. Após definir como uma das marcas da sociedade contemporânea a questão da espetacularizaçãao ${ }^{18}$, o autor busca pensar a ação política como uma ação direta sobre o corpo do espectador.

C'est la structure de la perception transmise par le média qui fait que, entre les images isolées reçues, et tout d'abord entre l'émetteur et le récepteur de signes, on ne distingue ni de rapport ni de relation énonciation/réponse. Le théâtre, par contre, pourrait réagir à cet état de fait, grâce à une politique de la perception qui serait à la fois une esthétique de la responsabilité.

E mais adiante :

le théâtre ne gagne pas sa realité esthétique et politico-éthique par le biais des informations, thèses, messages, toujours savamment édulcorés: bref, par son contenu au sens traditionnel. Au contraire, il appartient à son essence même de réaliser une peur, une violation des sentiments, une désorientation qui justement rencontre l'attention du spectateur sur sa présence par des processus qui peuvent apparaître "immoraux", "asociaux" et "cyniques": expérience "politique" par excellence. ${ }^{19}$

Desde Artaud, que já propunha a cena construída no calor da criação, a cena contemporânea vem produzindo experiências de contato com o espectador. No vasto campo da produção dramatúrgica atual, parece estar se consolidando uma fatia da qual vem emergindo não só procedimentos metodológicos, mas também uma linguagem estético-ideológica e uma pedagogia tanto para a formação do artista quanto para a do espectador: o teatro de grupo. Nesse sentido é que buscamos, nesse texto, iniciar a investigação da dramaturgia coletiva produzida no interior de grupos teatrais contemporâneos, para observar em que medida tal sistema implica na criação de uma dramaturgia polifônica. O Cena 3x4, a Casa das Misericórdias e a própria Maldita são frutos dessa investigação.

\section{Des(a)fiar}

Perseguir o inefável. A notação do indizível. Buscar na materialidade da cena os instrumentos para a escritura do que se apresenta pela primeira vez. Porque, segundo Artaud, a cena não mais representará. Esse é o limite da dramatur-

18 Conforme as teorias do intelectual situacionista Guy Debord, em A sociedade do espetáculo (La société do spectacle. Paris: Folio Essais, 1967).

19 "É a estrutura da percepção transmitida pela mídia que faz com que, entre as imagens isoladas recebidas, e sobretudo entre o emissor e o receptor de signos, não se distinga nem o produto nem a relação enunciação/resposta. $\mathrm{O}$ teatro, ao contrário, poderia reagir a este estado de fato, graças a uma política da percepção que seria, ao mesmo tempo, uma estética da responsabilidade. (...) o teatro não adquire sua realidade estética e político-ética pelo viés de informações, teses, mensagens, sempre sabiamente edulcoradas: em suma, por seu conteúdo no sentido tradicional. Ao contrário, pertence à sua própria essência realizar um medo, uma violação de sentimentos, uma desorientação que justamente atrai a atenção do espectador sobre sua presença por meio de processos que podem parecer "imorais", "associais" e "cínicos": esperiência "política” por excelência” (Lehmann, 2002, p. 294). 
gia da cena que procuramos perseguir. $\mathrm{Na}$ materialidade da cena, a ação sobre o espectador. ${ }^{20}$ Com o espectador , ele também criador da cena.

Com o espectador, a arte. Não aquela preconizada por Brecht, em sua mente. Mas em seu corpo presente, em jogo ${ }^{21}$, pois "para o Absoluto a própria vida é um jogo" (Artaud apud Derrida, 2005, p. 176). Não da re-presentação, mas daquilo que se apresenta, sempre novo, nessa polifonia. Será possível juntar Brecht a Artaud?

\section{Referências bibliográficas}

ARAÚJO, AC. A gênese da vertigem: o processo de criação de "O Paraíso Perdido". Dissertação (Mestrado). São Paulo: ECA/USP, 2002.

ARISTÓTELES. Poética. Tradução de Eudoro de Souza. São Paulo: Ars Poética, 1992.

ARTAUD, A. O teatro e seu duplo. São Paulo: Max Limonad, 1987.

BAKHTIN, M. Problemas da poética de Dostoiévski. Rio de Janeiro: Forense Universitária, 1987.

BARBA, E. \& SAVARESE, N. A arte secreta do ator: dicionário de antropologia teatral. São Paulo/ Campinas: Hucitec, 1995.

BARTHES, R. Oeuvres Complètes. Paris: Gallimard, 1990.

BORNHEIM, G. Brecht: a estética do teatro. Rio de Janeiro: Graal, 1992.

CERTEAU, Michel de. A Invenção do cotidiano: artes de fazer. Petrópolis: Vozes, 1994.

CHARAUDEAU, P. “Une analyse sémiolinguistique du discours". In: Langages, n. 117. Paris: Larousse, 1995.

COHEN, R. Work in progress na cena contemporânea: criação, encenação e recepção. São Paulo: Perspectiva, 2004b. (Estudos - Número 162)

DERRIDA, J. A escritura e a diferença. São Paulo: Perspectiva, 2005.

FERNANDES, S. Grupos teatrais: anos 70. Campinas: Editora da UNICAMP, 2000.

FOUCAULT, M. “O que é um autor?”. In: Ditos e Escritos, III. Rio de Janeiro: Forense Universitária, 2006.

20 "No teatro da crueldade, o espectador está no meio rodeado pelo espetáculo" (Artaud apud Derrida, 2005, p. 168).

21 Em francês, a palavra jogo tem essa dupla acepção: de representação e de brincadeira. 
GROTOVSKI, J. Em busca de um teatro pobre. Rio de Janeiro: Civilização Brasileira, 1992.

GUATTARI, F. Caosmose: um novo paradigma estético. São Paulo: Editora 34, 1992.

LEHMANN, H.-T. Le théâtre postdramatique. Paris: L'Arche, 2002.

O PERCEVEJO. Revista do Programa de Pós-Graduação em Teatro da Unirio. Rio de Janeiro: Editora da Unirio. Número 9, 1998.

PAVIS, P. Dicionário de Teatro. São Paulo: Perspectiva, 1999.

ROSENFELD, A. O teatro épico. Coleção Estudos. São Paulo: Perspectiva, 1990.

ROUBINE, J.-J: A linguagem da encenação teatral. Rio de Janeiro: Jorge Zahar Ed., 1998.

TODOROV, T. Poética da prosa. São Paulo: Martins Fontes, 2003. 